\section{Energy production of poplar clones and their energy use efficiency}

\author{
Gabriela Jamnická( ${ }^{(1)}$, Viera Petrášová ${ }^{(2)}$, Rudolf Petráš ${ }^{(3)}$, \\ Julian Mecko ${ }^{(3)}$, Július Oszlányi ${ }^{(4)}$
}

Poplar clones "Robusta" and "I-214" (Populus × euramericana) are characterized by fast growth and high quality biomass production. In this investigation the calorific value of these clones was determined, and modeling of the calorific production of a whole poplar clone stands in relation to stand age and site index was performed. Eleven trees were sampled in four sites in the eastern and seven in the western part of Slovakia. Samples of bark, wood and smallwood with bark were excised from three points along the stem and from two parts of the crown. No significant differences were observed between clones with regard to either the biomass fraction or the excising location. The average calorific capacity of all biomass fractions was approximately $6.86-8.73 \mathrm{GJ} \mathrm{m}^{-3}$, with the lowest bark values obtained for samples excised from the stem base. The mean annual calorific energy production for site index 20-40 was 320-380 GJ ha ${ }^{-1} \mathrm{y}^{-1}$ after 17-26 years since plantation, with the clone "I-214" culminating 1-2 years earlier than "Robusta". Energy use efficiency of these clones was estimated approximately $\mathbf{0 . 4 - 1 . 6 \%}$ of the incoming solar radiation.

Keywords: Biomass, Calorific Value, Energy Use Efficiency, Poplar Clones, Populus $\times$ euramericana

\begin{abstract}
Introduction
A fairly large portion of agricultural lands in Europe is suitable for plants of fast-growing tree species. Poplars have proven their efficacy in restoring functional and structural attributes of agro-ecosystems (Fortier et al. 2010, Raslavičius et al. 2013, Updegraff et al. 2004). Since this species produces valuable biomass for energy production (Hansen 1991), it is necessary not only to know the calorific value of its individual components, but also to understand the formation processes occurring throughout the tree existence. Poplar clones have a great advantage over other woody species because they produce a large amount of above-ground biomass during their relatively short life-cycle. Solar energy drives photosynthetic assimilation stored as chemical bonds in the biomass structural components, though the accumulated energy content can remarkably vary,
\end{abstract}

primarily depending on species growth over a determined time period. Moreover, stand age and site index affect the biomass production of forest tree species, influencing the obtainable volume and yield.

Yield tables for "Robusta" and "I-214" poplar clones published by Petráš \& Mecko (2005) predict not only biomass volumes for whole trees, but also for their main parts inponents, etc. Such partition of the whole yield in its different fractions is essential for industrial processing purposes. The volume obtained from yield tables is then converted to weight units based on the density of its different components. Many studies have reported that bark has lower density than wood (Knige \& Schultz 1966, Požgaj et al. 1997, Klašnja \& Kopitovič 1999), and soft broadleaf species have registered the lowest wood density, followed by coniferous and hard cluding stem, large wood, under-bark com-

(1) Slovak Academy of Sciences-Institute of Forest Ecology, Štúrova 2, SK-96053 Zvolen (Slovakia); (2) Slovak University of Agriculture in Nitra, A.Hlinku 2, SK-94976 Nitra (Slovakia); (3) National Forest Centre,Forest Research Institute, T.G.Masaryka 22, Zvolen (Slovakia); (4) Slovak Academy of Sciences, Institute of Landscape Ecology, Štefánikova 3, SK-81499 Bratislava (Slovakia)

@ Gabriela Jamnická (jamnicka@sav.savzv.sk)

Received: Feb 21, 2013 - Revised: Aug 23, 2013 - Final Acceptance: Nov 21, 2013

Citation: Jamnická G, Petrášová V, Petráš R, Mecko J, Oszlányi J, 2014. Energy production in poplar clones and their energy use efficiency. iForest 7: 150-155 [online 2014-01-23] URL: http://www.sisef.it/iforest/contents/?id=ifor0978-007

Communicated by: Francesco Ripullone broadleaf species. Petráš et al. (2010) derived average densities of above-ground biomass fractions in the range of $350-470 \mathrm{~kg}$ $\mathrm{m}^{-3}$ for two clones of Populus $\times$ euramerica$n a$, and a similar wood density of 306-367 $\mathrm{kg} \mathrm{m}^{-3}$ was recorded for 4 clones of Populus $\times$ deltoides by Kord \& Samdaliri (2011). In addition, wood density varies not only according to species considered but also to the excising location along the tree (Požgaj et al. 1997, Husch et al. 2003, Petráš et al. 2010).

Besides the evaluation of a species' calorific value, it is important to assess the relative efficiency of woody species in using the solar radiation. Pretzsch (2009) named this characteristic "energy use efficiency", defined as the ratio between the energy accumulated in the above-ground biomass and the incoming solar radiation. For example, the average annual sum of global radiation for Germany is approximately $36000 \mathrm{GJ} \mathrm{ha}^{-1} \mathrm{y}^{-1}$. Since net biomass production for Norway spruce, European beach, Scots pine, Sessile and Common oak is in the range 0.005-0.009, their energy use efficiency is less than $1 \%$ (Pretzsch 2009). Indeed, Larcher (2003) and Körner (2002) reported that $50-60 \%$ of incoming radiation is outside the photosynthetically useful spectrum, and a further 10-20 $\%$ is reflected or transmitted, while most of the remainder is lost in the photosynthetic process.

The aims of this analysis were: (i) to determine the calorific values of above-ground biomass for poplar clones "Robusta" and "I214"; (ii) to examine the above-ground biomass of wood, bark and small-wood with bark in order to establish which fraction has the highest calorific capacity; (iii) to derive the calorific energy content and energy use efficiency of clones at the stand level; and (iv) to establish the most appropriate exploitation strategy of poplar clones for energy production purposes.

\section{Materials and methods}

\section{Study sites}

Eleven trees were sampled in poplar stands located in the southern area of western (7 stands) and eastern (4 stands) Slovakia, at elevations ranging from 100 to $300 \mathrm{~m}$ a.s.l. (Fig. 1). Average annual temperature in these regions is $9.0-10.0{ }^{\circ} \mathrm{C}$, and vegetation period is approximately 180 days. Most poplar stands were affected by ground water from surrounding rivers.

The site index $q$ indicates the fertility of a location based on the mean tree height after 30 years since the establishment (Petráš \& Mecko 2005). For example, a site index of 40 indicates that a 30 -years-old poplar stand attains a mean height of 40 meters. Additional characteristics of the sampled stands including age, diameter at breast height $(D B H)$ 


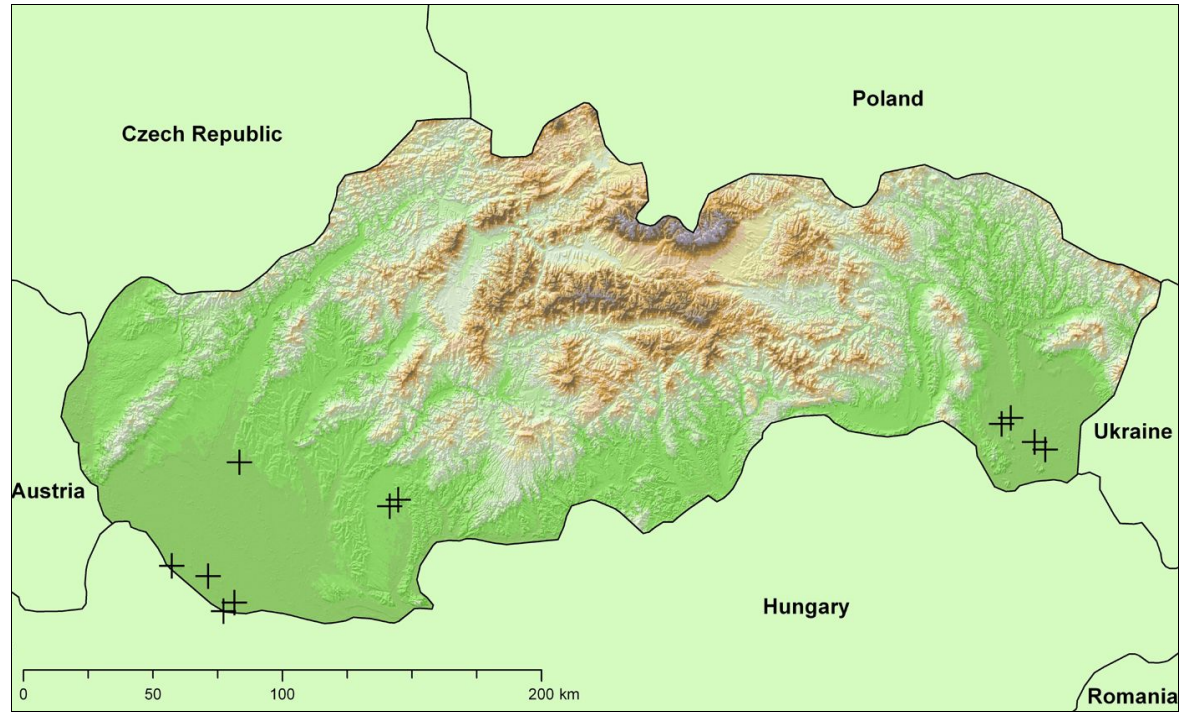

Fig. 1 - Location of study sites in western and eastern Slovakia, indicated by black crosses.

Tab. 1 - Basic growth characteristics of the sampled poplar trees. (DBH): diameter at breast height.

\begin{tabular}{lccccc}
\hline Clone & $\begin{array}{c}\text { Number of } \\
\text { trees }\end{array}$ & Age & DBH & Height & Site index \\
\hline "Robusta" & 5 & $22-44$ & $35-49$ & $30-41$ & $24-34$ \\
"I-214" & 6 & $19-47$ & $34-56$ & $25-40$ & $22-40$ \\
\hline
\end{tabular}

Tab. 2 - Percentage distribution of annual global radiation in each months (1997-2002).

\begin{tabular}{ccccccccccccc}
\hline Month & Jan & Feb & Mar & Apr & May & Jun & Jul & Aug & Sep & Oct & Nov & Dec \\
\hline$\%$ & 2.5 & 4.3 & 7.6 & 10.6 & 13.9 & 14.8 & 14.7 & 12.8 & 8.6 & 5.7 & 2.6 & 1.9 \\
\hline
\end{tabular}

and tree height are reported in Tab. 1.

\section{Sampling and analysis}

Samples were taken from the following five tree segments: (1) the base, middle and top part of each stem provided three wood and bark samples; and (2) two small-wood samples were taken from the crown, one 4-6 $\mathrm{cm}$ in diameter and the other $<4 \mathrm{~cm}$. A total of 88 samples were obtained, of which 33 wood, 33 bark and 22 small-wood samples with bark. Fresh volume of samples was determined to the nearest $1 \mathrm{ml}$ in a calibrated cylinder. Dry weight was measured after oven-drying at $105{ }^{\circ} \mathrm{C}$ using a $0.01 \mathrm{~g}$ precision scale. Samples were then ground with a Retsch cutting mill (Gmbh, Germany) and

homogenized by thorough mixing. The calorific values (as Higher Heating Values) of dry matter $\left(C V D M-\left[\mathrm{J} \mathrm{g}^{-1}\right]\right)$ were determined by the $\mathrm{C}-200$ calorimeter according to the Standard ISO 1928:2009 for solid mineral fuels. Four repetitions per sample were carried out.

\section{Calculation procedures}

The calorific production of the aboveground biomass for clones was derived by recalculation from its volume production. This was achieved using the yield tables' model for the "Robusta" and "I-214" poplar clones (Petráś \& Mecko 2001, 2005), their biomass densities (Petráš et al. 2010) and the calorific value of the biomass dry matter.

Tab. 3 - Density, calorific dry matter and calorific capacity of the "Robusta" and "I-214" poplar clones analyzed. Mean values ( \pm standard deviation) of calorific content are reported.

\begin{tabular}{llccc}
\hline Characteristics & Clone & Bark & Wood & Small-Wood \\
\hline Density $\left(\mathrm{kg} \mathrm{m}^{-3}\right)$ & "Robusta" & $389.39 \pm 29.99$ & $427.47 \pm 37.45$ & $468.98 \pm 39.36$ \\
& "I-214" & $385.25 \pm 33.79$ & $392.96 \pm 58.49$ & $456.72 \pm 22.49$ \\
\hline Calorific value of & "Robusta" & $17975 \pm 547$ & $18350 \pm 468$ & $18589 \pm 553$ \\
dry matter $\left(\mathrm{J} \mathrm{g}^{-1}\right)$ & "I-214" & $17801 \pm 473$ & $18492 \pm 359$ & $18307 \pm 348$ \\
\hline Calorific value & "Robusta" & $7.01 \pm 0.65$ & $7.85 \pm 0.76$ & $8.73 \pm 0.93$ \\
capacity $\left(\mathrm{GJ} \mathrm{m}^{-3}\right)$ & "I-214" & $6.86 \pm 0.61$ & $7.27 \pm 1.10$ & $8.36 \pm 0.51$ \\
\hline
\end{tabular}

Yield tables predict the biomass volume $\left(V B-\mathrm{m}^{3} \mathrm{ha}^{-1}\right)$ based on age $t$ and site index $q$ as follows (eqn. 1):

$$
V B=f(t, q)
$$

Biomass volume was thus obtained for whole-tree wood components, stem and large wood elements. All volumes (over-bark and under-bark) were given for mixed coppice, main stand, secondary crop, total production and also for total current annual and total mean periodic increments.

The calorific value capacity $\left(C V C-\mathrm{GJ} \mathrm{m}^{-3}\right)$ was calculated from measured density values $\left(D-\mathrm{kg} \mathrm{m}^{3}\right)$ and $\operatorname{CVDM}\left(\mathrm{J} \mathrm{g}^{-1}\right)$ as follows (eqn. 2):

$$
C V C=D \cdot C V D M \cdot 10^{-6}
$$

The calorific energy content of whole stand $\left(C E C-\mathrm{GJ} \mathrm{ha}^{-1}\right)$ was then derived by replacing in eqn. 2 the average value of calorific capacity (eqn. 3 ):

$$
C E C=V B \cdot C V C
$$

The final model then predicts the calorific energy production (CEP - GJ ha $\left.{ }^{-1}\right)$ of poplar clone stands based on age $t$ and site index $q$ (eqn. 4):

$$
C E P=f(t, q)
$$

The energy use efficiency throughout the life-cycle $(E U E$ - \%) was derived according to Larcher (2003) and Pretzsch (2009), as the ratio of the energy accumulated in the above-ground biomass (AGTB - GJ ha ${ }^{-1}$ ) and the incoming solar energy as follows (eqn. 5):

$$
E U E=\frac{C E P_{A G T B}}{R_{M a y-S e p}}
$$

where $C E P_{\mathrm{AGTB}}$ is the calorific energy production in the above-ground trees biomass $\left(\mathrm{GJ} \mathrm{ha}^{-1}\right)$, and $R_{\text {May-Sep }}$ is the incoming global radiation $\left(\mathrm{GJ} \mathrm{ha}^{-1}\right)$ over the vegetation period (May-September).

Data for annual global radiation were taken from the meteorological observatory at the Geophysical Institute of the Slovak Academy of Science in Mlynany, Slovakia (long. $18^{\circ}$ $20^{\prime} \mathrm{E}, 48^{\circ} 19^{\prime} \mathrm{N}$ ), at an approximate elevation of $195 \mathrm{~m}$ a.s.l. Recorded average annual global radiation was $436212 \mathrm{~kJ} \mathrm{~cm}^{-2} \mathrm{y}^{-1}$ (43 621.2 GJ ha-1 $\mathrm{y}^{-1}$ ) for the period 19702002 (Ostrožlík 2003). The incoming radiation for the period considered in this study (May to September) represents the $64.8 \%$ of the annual total radiation (Tab. 2).

\section{Statistical analysis}

Analysis of variance was applied to test for differences in calorific value capacity obtained from eqn. 2 , using the following three 
factors: (1) the clone ("Robusta" and "I214"); (2) the excising location on the tree (base, middle and top of the tree stem plus 4$6 \mathrm{~cm}$ and $<4 \mathrm{~cm}$ small wood); and (3) the biomass fraction (wood, bark and smallwood with bark). Tukey's post-hoc HSD test was applied to test for differences in mean values $(\alpha=0.05)$.

\section{Results and discussion}

Calorific values of biomass fractions

Density $\left(\mathrm{kg} \mathrm{m}^{-3}\right)$, calorific values of dry matter $\left(\mathrm{J} \mathrm{g} \mathrm{g}^{-1}\right)$ and calorific value capacity (GJ $\mathrm{m}^{-3}$ ) were obtained for each of the three biomass fractions considered for each clone (Tab. 3). Results of the analysis of variance carried out may be summarized as follows: (1) overall, the influence of the factors explored in the analysis was statistically significant $(\mathrm{p}<0.001$ - Tab. 4); (2) the influence of the individual factors considered on biomass calorific value was statistically significant except for the clone (Tab. 5); (3) the post-hoc test applied confirmed that differences in the average calorific content do exist among the three biomass fractions analyzed ( $<<0.05$ - Fig. 2); and (4) significant differences in the calorific value capacity were detected only between the three crown parts and the other two parts of the stem (the base and the middle). The above results indicate that stem wood from these poplar clones can be advantageously utilized for mechanical and chemical purposes.

Energy content in plant tissues is proportional to their carbon content. Larcher (2003) asserted that the greatest energy content in plant tissues is due to lignin $(26.4 \mathrm{~kJ}$ $\left.\mathrm{g}^{-1}\right)$, lipids $\left(38.9 \mathrm{~kJ} \mathrm{~g}^{-1}\right)$, and terpenes $(46.9$ $\left.\mathrm{kJ} \mathrm{g}^{-1}\right)$. Accordingly, in this study the highest calorific content was found for small-wood, likely depending on the higher abundance of the above-mentioned tissues in this biomass fraction.

Fig. 3 - The calorific energy production in poplar clone biomass, dependent on stand age and site index (SI) 20, 30 and 40.

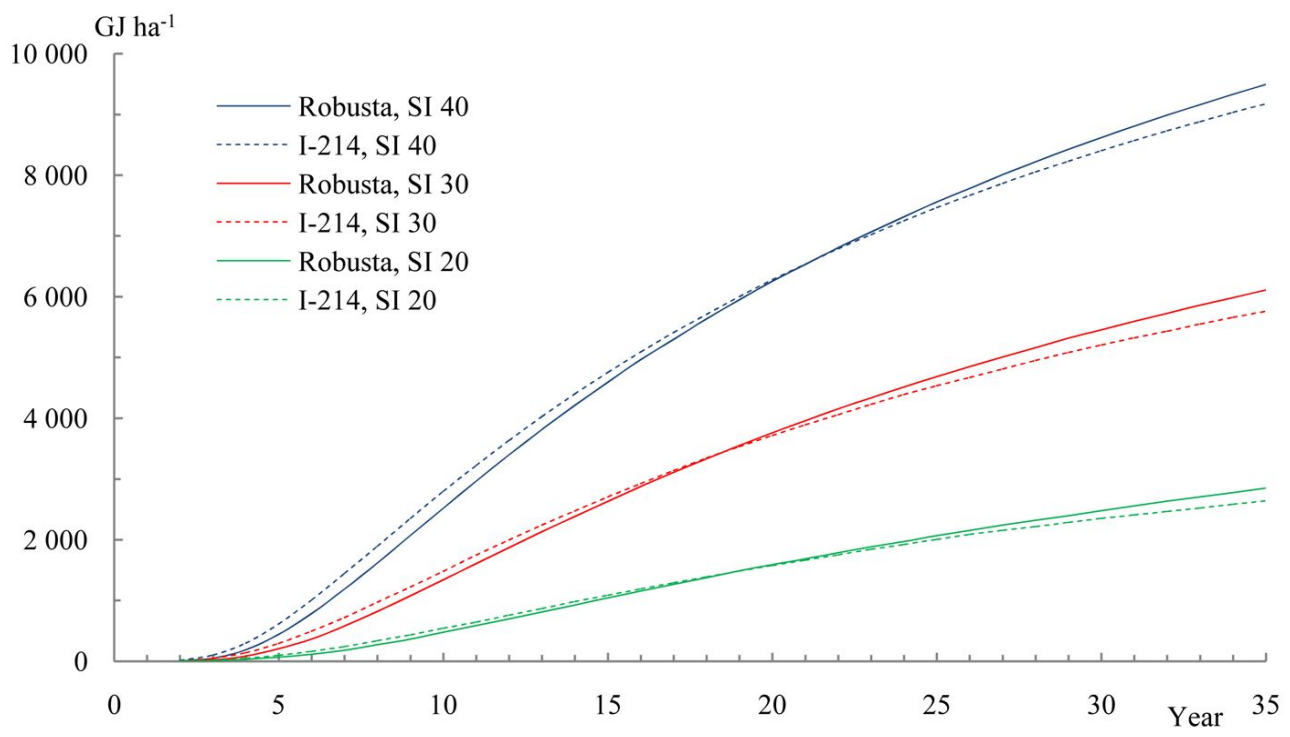

Tab. 4 - Results of the ANOVA on the poplar clones' calorific value using the clone, the ex cising location on the tree and the biomass fraction as factors.

\begin{tabular}{lccc}
\hline Source of variability & Sum of Squares & F-statistic & p-value \\
\hline Total & 89.66 & - & - \\
Explained & 51.74 & 2.36 & $3.72 \mathrm{E}-05$ \\
Residual & 37.92 & - & - \\
\hline
\end{tabular}

Tab. 5 - Results of the one-way ANOVA carried out to test the influence of individual factors on poplar clones' calorific value.

\begin{tabular}{lccl}
\hline Factors & Sum of Squares & F-statistic & p-value \\
\hline Biomass fraction & 34.12 & 26.11 & $1.32 \mathrm{E}-09$ \\
Excising Location on the tree & 42.74 & 18.90 & $3.25 \mathrm{E}-11$ \\
Clone & 2.90 & 2.87 & 0.094 \\
\hline
\end{tabular}

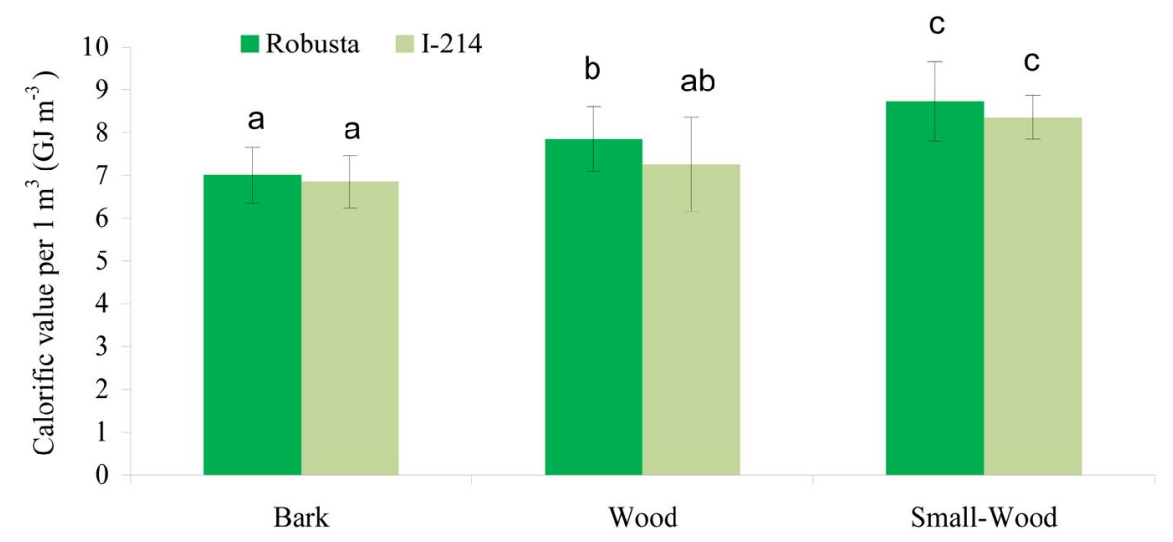

Fig. 2 - Mean ( \pm SE) calorific capacity of basic biomass fractions in "Robusta" and "I-214" poplar clones. Different letters indicate significant differences among the means $(\mathrm{P}<0.05)$ according to the post-hoc Tukey HSD test.

\section{Modeling of calorific energy content}

Since the yield tables used in this study predict only the volume for wood, bark and small-wood with bark, a simplification in the calculation of the calorific energy production was applied according to eqn. 4.

The life-time calorific energy production obtained from the model applied as a function of stand age and site index is displayed in Fig. 3. The growth curves starts with values accrued from the second year of the growth tables, given that values before that age are close to zero. However, after 35 years and at site indexes of 20,30 and 40 , 

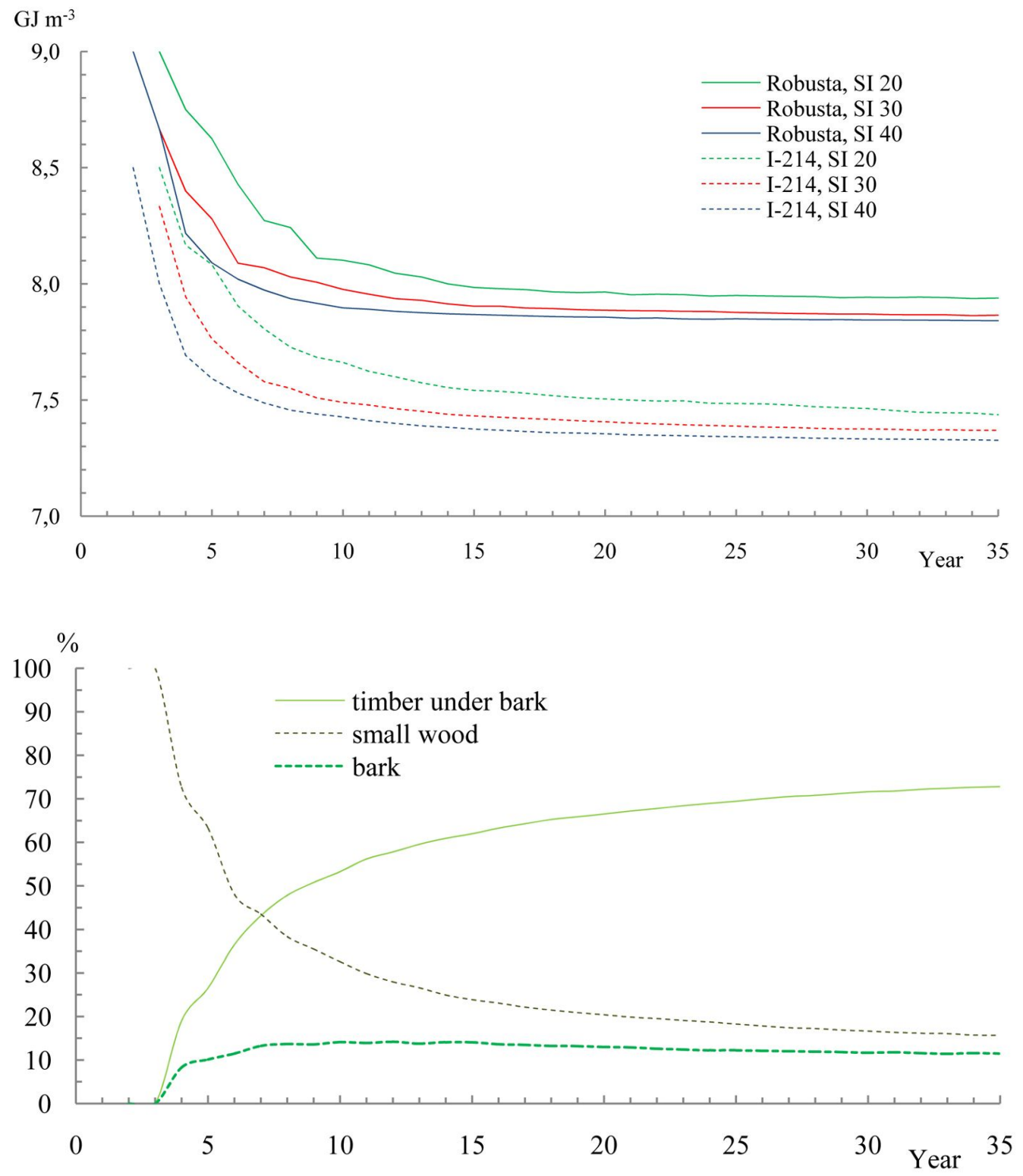

Fig. 4 - The average calorific capacity in $1 \mathrm{~m}^{3}$ of poplar clone biomass, dependent on stand age and site index (SI) 20, 30 and 40 .

Fig. 5 - The proportion of calorific energy production in wood, bark and small-wood for the "Robusta" clone at site index 30 .
Fig. 6 - Annual increments in poplar biomass calorific energy, dependent on stand age and site index (SI) 20, 30 and 40 .

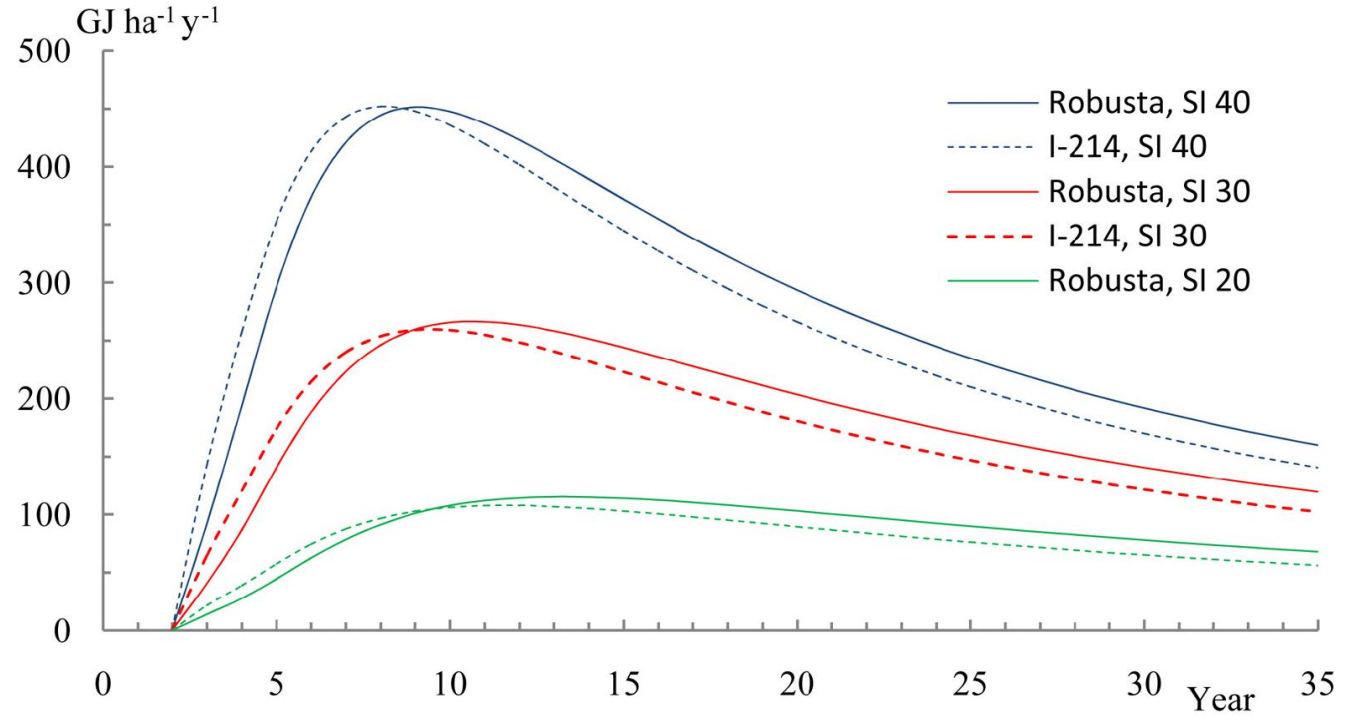


Fig. 7 - Average annual biomass calorific energy production, dependent on stand age and site index (SI) 20 , 30 and 40

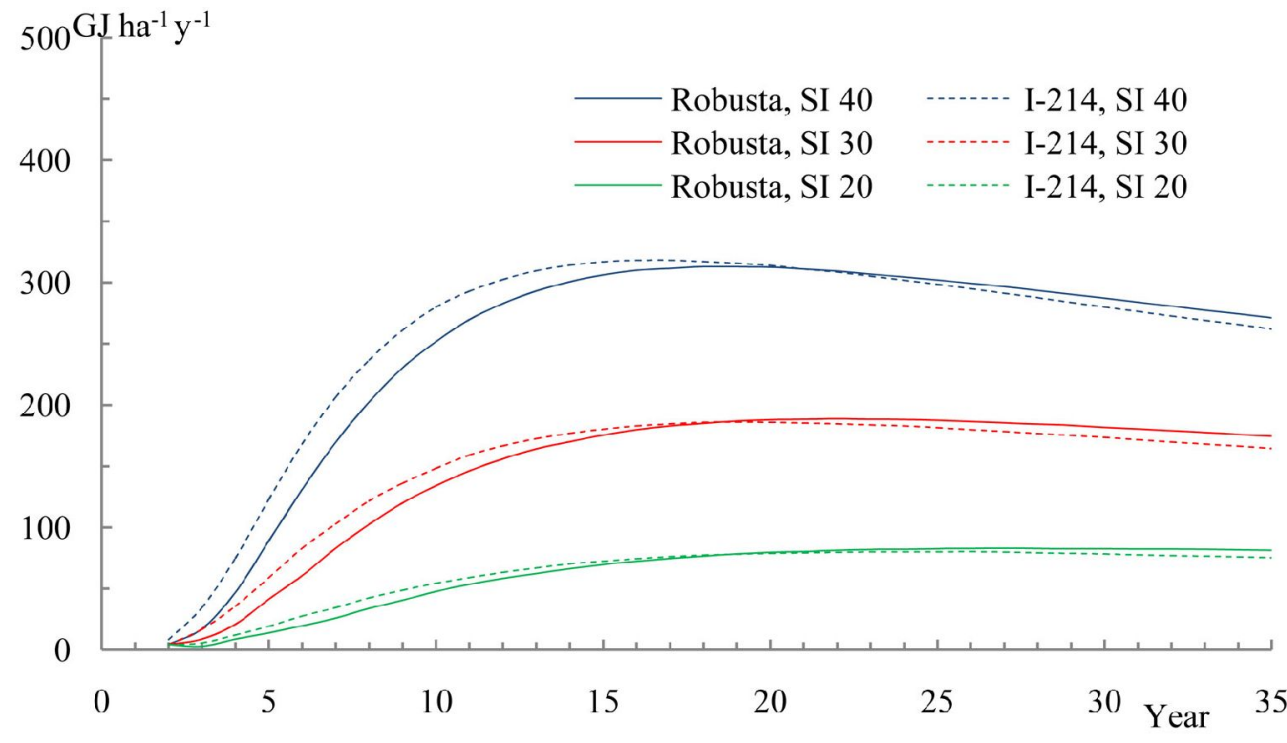

Fig. 8 - Energy use efficiency of poplar clone biomass calorific production, dependent on stand age and site index (SI) 20, 30 and 40 .

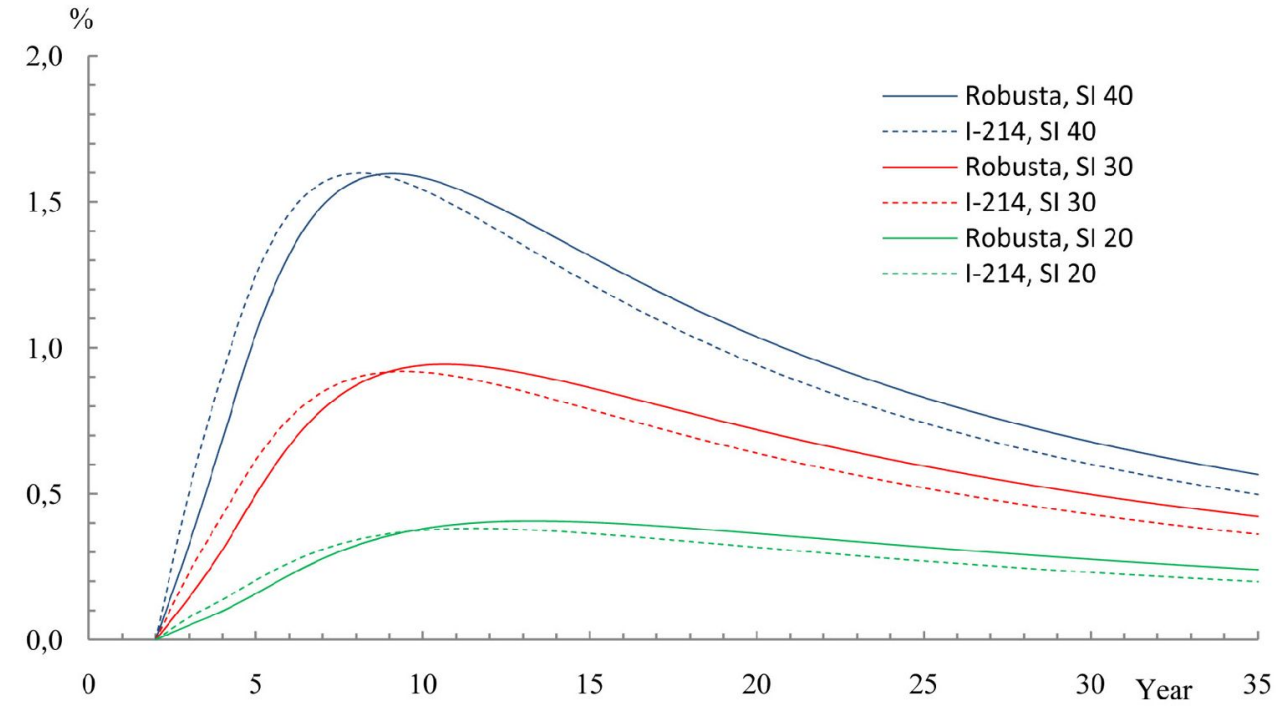

the estimated calorific energy productions are approximately 2700,6000 and 9300 GJ $\mathrm{ha}^{-1}$, respectively. Clone "I-214" had a slightly higher calorific production than "Robusta" during the first half of its rotation time, the latter clone recording 7.8-8.0 GJ $\mathrm{m}^{-3}$ in the middle-late years and site indexes 40-20, while "I-214" clone had just 0.5 GJ $\mathrm{m}^{-3}$ less.

However, larger differences between the clones analyzed were observed when the calorific value per $\mathrm{m}^{3}$ of biomass at lower site indexes was considered (Fig. 4). Indeed, a significant reduction in the calorific value from the $2^{\text {nd }}$ to the $5^{\text {th }}$ year of growth was observed.

As mentioned above, calorific capacity accumulated differently in the different biomass fractions as a function of a varying proportion of lignin, terpenes and essential oils contained in the tissues (Fig. 5). After 35 years since plantation, $73 \%$ of the calorific value was stored in the wood, $16 \%$ in the small-wood component, and $11 \%$ in the bark. It is should be noted here that the decrease in bark calorific capacity was quite low, reducing only from $15 \%$ to $11 \%$ over a twenty year period.

Annual increment estimates in calorific energy content culminated approximately at age 8-13 in the 20-40 site indexes, with a value of 110-450 GJ ha-1 $\mathrm{y}^{-1}$ (Fig. 6), the "I214" clone culminating 1-2 years earlier than "Robusta". The calorific value then markedly decreased with increasing age to approximately $60-160 \mathrm{GJ} \mathrm{ha}^{-1} \mathrm{y}^{-1}$ after 35 years. As a comparison to hard broadleaf species, Bublinec et al. (2011) found that the average annual increment of energy content in aboveground biomass in a 75 years-old beech stand was approximately $176 \mathrm{GJ} \mathrm{ha}^{-1} \mathrm{y}^{-1}$.

The estimated average annual production of calorific energy content (Fig. 7) for site indexes 20-40 culminated approximately 17 26 years after plantation, with values of 80 $320 \mathrm{GJ}^{\mathrm{J}} \mathrm{ha}^{-1} \mathrm{y}^{-1}$, the "I-214" clone culmina- ting again 2-3 years earlier than "Robusta". This value can be compared with the highest annual increment of $450 \mathrm{GJ} \mathrm{ha}^{-1} \mathrm{y}^{-1}$ recorded for 8-9 years-old poplar stands on aboveaverage site indexes in the temperate climatic zone in Central Europe. According to the above evidence, it is recommended to harvest the poplar clone stands at this age, since the average annual energy production under these conditions is lower both before and after this time.

\section{Energy use efficiency}

The energy use efficiency calculated by eqn. 5 for "Robusta" and "I-214" poplar clones has a similar relationship to their annual calorific production increments (Fig. 8). solar radiation usage (approximately 1.6\%) at 8-9 years after plantation at the highest site indexes. This value, however, markedly decreases with lower site index and higher age, attaining only $0.2-0.6 \%$ by age 35 . As Poplar clones stands achieve their maximum 
for comparison, Bublinec et al. (2011) report that beech ecosystems in Central Europe effectively utilize less than $1 \%$ during the photosynthetic activity period (May to September). Moreover, Pretzsch (2009) reported energy use efficiency values of $0.8-0.9 \%$ for spruce and pine in Germany and 0.5-0.6\% for broadleaf species.

Based on our estimates, poplar clones received $28267 \mathrm{GJ}^{\mathrm{ha}}{ }^{-1}$ solar radiation during the period May to September, while Pretzsch (2009) calculated $36000 \mathrm{GJ}^{-1} \mathrm{a}^{-1}$ over the entire year. The above difference may be due to the fact that the latter estimate is based only on the marketable wood quantities from the national forest inventory. However, it is widely accepted that total above-ground biomass volume is much larger, exceeding 8 $10 \%$ for coniferous species and $12-15 \%$ for broadleaves. Although Larcher (2003) reported similar energy use efficiency values, with a $2 \%$ limit for forest stands, the solar radiation usage reported for most woody species was less than $1 \%$.

\section{Conclusions}

The poplar clones "Robusta" and "I-214" poplar clones have high above-ground biomass production, eminently suitable for biofuel energy. Crown small-wood provided 0.8 GJ $\mathrm{m}^{-3}$ higher calorific value capacity than stem wood, and wood from the base and the middle of the poplar stems had $1 \mathrm{GJ} \mathrm{m}^{-3}$ less than the crown parts. Moreover, the bark re gistered only approximately a $0.61 \mathrm{GJ} \mathrm{m}^{-3}$ lower calorific capacity than the wood. The above findings are especially valuable in the light of industrial exploitation of the poplar clones' biomass, since industrial energy utilization efficiency must include costs for both production and transport to the consumption point.

A calorific energy content of approximately $5000 \mathrm{GJ} \mathrm{ha}^{-1}$ is available from the burned biomass of poplar clones at above-ave- rage site indexes, with a $25 \%$ decrease below-average sites. Therefore, the energy content of a 30 years-old poplar stand is similar to the $5137 \mathrm{GJ}^{\mathrm{a} a}{ }^{-1}$ reported by Bublinec et al. (2011) for a 75 years-old beech stand.

In addition to their fast growth, large biomass and high calorific production, poplar clones "Robusta" and "I-214" also exhibited a particularly high energy use efficiency compared to other wood species. Moreover, most poplar stands in this study accumulated more than $1 \%$ of the solar radiation.

\section{Acknowledgments}

This research was supported by grants from the Slovak Research and Development Agency, Project No. APVV-0131-07, and from the Slovak Grant Agency VEGA No. 2/0006/11.

\section{References}

Bublinec E, Kuklová M, Oszlányi J (2011). Phytometry and energy distribution in beech ecosystems. In: "Beech and beech ecosystems of Slovakia" (Barna M, Kulfan J, Bublinec E eds). VEDA, Bratislava, Slovakia, pp. 289-327.

Fortier J, Gagnon D, Truax B, Lambert F (2010). Biomass and volume yield after 6 years in multiclonal hybrid poplar riparian buffer strips. Biomass and Bioenergy 34: 1028-1040. - doi: 10.10 16/j.biombioe.2010.02.011

Hansen EA (1991). Poplar woody biomass yields: a look to the future. Biomass and Bioenergy 1: 17. - doi: 10.1016/0961-9534(91)90046-F

Husch B, Beers TW, Kershaw JA (2003). Forest mensuration. John Wiley \& Sons, New Jersey, USA.

Klašnja B, Kopitovič Š (1999). Quality of wood of some willow and robinia clones as fuelwood. Wood Research 44 (2): 9-18. [online] URL: http://www.cabdirect.org/abstracts/20000610565 .html

Knige W, Schultz H (1966). Grundriss der Forstbenutzung. Verlag, Hamburg, Berlin, Germany. Kord B, Samdaliri M (2011). The impact of site index on wood density and fiber biometry of Populus deltoides clones. World Applied Sciences Journal 12: 716-719. [online] URL: http:// www.idosi.org/wasj/wasj12(5)/21.pdf

Körner C (2002). Ökologie. In: "Strasburger Lehrbuch für Botanik" (Sitte P, Weiler EW, Kadereit JW, Bresinsky A, Körner C eds). Spektrum Akademischer Verlag, Heidelberg, Berlin, Germany, pp. 886-1043.

Larcher W (2003). Physiological plant ecology. Ecophysiology and stress physiology of functional groups. Springer, Berlin, Germany.

Ostrožlík M (2003). Long-term changes of the global solar radiation in Mlynany. In: Proceedings of the International Workshop "Mikroklima porostu" (Rožnovský J, Litschmann T eds). Brno (Czech Republic) 26 March 2003. Brno, Slovakia, pp. 23-28. [In Slovak]

Petráš R, Mecko J (2001). Erstellung eines mathematischen Modells der Ertragstafeln für Pappelklone in der Slowakei. Allgemeine Forst und Jagd-Zeitung 172 (2): 30-34.

Petráš R, Mecko J (2005). Growth tables of poplar clones. Slovak Academic Press, Bratislava, Slovak Republic. [In Slovak]

Petráš R, Mecko J, Neuschlová E (2010). Density of basic components of above-ground biomass of poplar clones. Wood Research 55 (4): 113-122.

Požgaj A, Chovanec D, Kurjatko S, Babiak M (1997). Structure and properties of wood. Príroda, Bratislava, Slovak Republic. [In Slovak]

Pretzsch H (2009). Forest dynamics, growth and yield. Springer, Heidelberg, Berlin, Germany. Raslavičius R, Kučinskas V, Jasinskas A (2013). The prospects of energy forestry and agroresidues in the Lithuania's domestic energy supply. Renewable and Sustainable Energy Reviews 22: 419-431. - doi: 10.1016/j.rser.2013.01.045

Updegraff K, Baughman MJ, Taff SJ (2004). Environmental benefits of cropland conversion to hybrid poplar: economic and policy considerations. Biomass and Bioenergy 27: 411-428. doi: 10.1016/j.biombioe.2004.05.002 